Article

\title{
The Influence of Cross-Cultural Awareness and Tourist Experience on Authenticity, Tourist Satisfaction and Acculturation in World Cultural Heritage Sites of Korea
}

\author{
Hao Zhang ${ }^{1}$, Taeyoung Cho ${ }^{2}$, Huanjiong Wang ${ }^{1, *(1)}$ and Quansheng Ge ${ }^{1, *}$ \\ 1 Key Laboratory of Land Surface Pattern and Simulation, Institute of Geographic Sciences and Natural \\ Resources Research, Chinese Academy of Sciences, 11A, Datun Road, Chaoyang District, \\ Beijing 100101, China; zhanghao@igsnrr.ac.cn \\ 2 Department of Airline Service Science, Joongbu University, 201 Daehak-ro, Chubu-myeon, Geumsan-gun, \\ Chungnam 312-702, Korea; tyc@daum.net \\ * Correspondence: wanghj@igsnrr.ac.cn (H.W.); geqs@igsnrr.ac.cn (Q.G.); Tel.: +86-10-6488-9831 (H.W.); \\ +86-10-6488-9499 (Q.G.)
}

Received: 12 January 2018; Accepted: 20 March 2018; Published: 23 March 2018

check for

\begin{abstract}
This study aimed to identify the relationship among the following factors: cross-cultural awareness, tourist experience, authenticity, tourist satisfaction, and acculturation. It also sought to determine what role that tourist activities play in acculturation. Furthermore, this study looked to provide a feasibility plan for the effective management, protection, and sustainable development of World Cultural Heritage Sites. We chose Chinese in Korea (immigrants, workers, and international students) who visited the historic villages of Korea (Hahoe and Yangdong) as the research object, and used 430 questionnaires for analysis. The confirmatory factor analysis and structural equation model were used to verify proposed hypotheses. The results showed that (1) Chinese in Korea, who have higher cultural awareness, had more interests in objective authenticity (e.g., historical traditions, cultural heritage, and architecture) of world heritage sites; (2) Chinese in Korea could feel and appreciate the true value of traditional culture through tourist experience; (3) The objective authenticity and existential authenticity have a positive effect on tourist satisfaction; and, (4) Higher tourist satisfaction could effectively promote cultural integration and assimilation, and prevent cultural separation and marginalization.
\end{abstract}

Keywords: cross-cultural awareness; tourist experience; authenticity; tourist satisfaction; acculturation; world cultural heritage sites; Chinese in Korea

\section{Introduction}

According to a survey by the World Tourism Organization (UNWTO), about $40 \%$ of international tourists prefer to visit locations of significant cultural heritage, including world cultural heritage sites, cultural sites, museums, and antiquities [1]. With the growth of tourists for cultural heritage, a new tourism market has been formed. Living in sophisticated, diverse, and technologically advanced times, modern people want to discover the value of cultural heritage and feel nostalgia for old things. Thus, the demand for diversification of cultural heritage tourism is increasing.

Since 2010, the number of Chinese tourists visiting Korea has increased. In 2016, the number of visitors reached $8,067,700$, accounting for $46.8 \%$ of the total inbound tourists [2]. There are a variety of factors that are causing this increase, such as the expansion of economic exchange, the growth of shopping-related to cultural tourism, the simplification of the visa process, increased individual visits, 
the growing international influence of Korean popular culture, and so on [2]. Korea has tried to increase tourism income and has made many preparations for the continuous growth of Chinese tourists, which is the first inbound market of the world heritage sites in Korea. Furthermore, in the age of cultural enjoyment, as a flexible, historical, artistic, social, educational, and high-value-added tourism form, cultural heritage tourism has been competitive in attracting tourists by characterizing the unique cultural authenticity of the country [3]. Therefore, to provide a theoretical basis for future development of cultural heritage tourism, it is necessary to investigate the various aspects of Chinese visitors for cultural heritage sites of Korea, such as cross-cultural awareness, tourist experience, authenticity, tourist satisfaction, and acculturation.

In addition, Korea has become a multicultural society. To date, foreigners living in Korea make up $2 \%$ of the total population. The number of foreign nationals living in Korea is predicted to reach $5 \%$ by $2020,6 \%$ by 2030 , and $10 \%$ by 2050 . For multicultural families, immigrants, workers, international students, etc., it is necessary to take various measures to adapt to Korean culture [4]. Tourist satisfaction may promote cultural integration and assimilation [4]. Thus, tourism can be an effective solution to human rights violations, cultural contradictions, and other problems [5]. However, limited research has focused on the relationship between tourism and cultural adaptation.

In the present study, we selected the historic villages of Korea: Hahoe and Yangdong, as our research sites, because both of them are listed as World Heritage Sites and are very attractive places, which reflect the Confucian culture of the Joseon Dynasty. Based on a questionnaire survey, we investigated the relationship among cross-cultural awareness, tourist experience, authenticity, tourist satisfaction, and acculturation of Chinese people that are living in Korea. The purposes of this study are (1) to understand the role that tourism played in the acculturation of Chinese in Korea, and (2) to figure out the role of tourism activities in helping cultural adaptation of Chinese in Korea (3) to provide practical suggestions for the sustainable development of world heritage tourism.

\section{Literature Review and Research Hypotheses}

\subsection{Literature Review}

\section{(1). Cross-cultural awareness}

Cross-cultural awareness can be said to be a process or desire to adapt to another country or culture that is different from its own culture [6]. Dodd [7] pointed out that cultural differences have a significant impact on communication methods and relationships. Furthermore, cross-cultural awareness not only gives people an incentive to understand their own culture, but can also develop attitudes that recognize and accommodate cultural differences. Therefore, cross-culture awareness is regarded as a driving force to develop skills and abilities to overcome cultural differences. Cross-cultural awareness may also include the desire to know about other countries or other cultures through tourism activity. Along with the increase of cross-cultural tourism, the consumers' tastes changed from the repetitive and passive activities to pursue new experiences [8]. In this study, whether the Chinese in Korea has the awareness to understand and learn Korean culture was chosen to represent cross-cultural awareness (Table 1).

Table 1. Questionnaire design.

\begin{tabular}{ll}
\hline Variables (Sub Variables) & Items \\
\hline & CC1. Need to learn Korean. \\
& CC2. Want to live in Korea. \\
Cross-cultural Awareness & CC3. Can accept Korean lifestyle. \\
& CC4. Can learn a lot of other cultures by tourism. \\
& CC5. Want to experience Korean culture. \\
\hline
\end{tabular}


Table 1. Cont.

\begin{tabular}{|c|c|}
\hline Variables (Sub Variables) & Items \\
\hline Tourist Experience & $\begin{array}{l}\text { TE1. The experience of Confucian culture was fun. } \\
\text { TE2. The experience of traditional life was interesting. } \\
\text { TE3. Able to learn the Traditional culture. } \\
\text { TE4. Acquire new knowledge via tourist experience. } \\
\text { TE5. Experiencing varied cultural landscapes via tourist experience }\end{array}$ \\
\hline $\begin{array}{l}\text { Authenticity } \\
\text { (Objective Authenticity) }\end{array}$ & $\begin{array}{l}\text { OA1. Acquire knowledge of world cultural heritage. } \\
\text { OA2. Experience the native culture of world cultural heritage. } \\
\text { OA3. Confirm the authenticity of relics. } \\
\text { OA4. Confirm the excellence of world cultural heritage. } \\
\text { OA5. Confirm culture of life. }\end{array}$ \\
\hline $\begin{array}{l}\text { Authenticity } \\
\text { (Constructed Authenticity) }\end{array}$ & $\begin{array}{l}\text { CA1. Cultural heritage is preserved well. } \\
\text { CA2. History and culture can reappear through cultural heritage. } \\
\text { CA3. Traditional life can reappear. } \\
\text { CA4. Korean traditional culture color is very strong. }\end{array}$ \\
\hline $\begin{array}{l}\text { Authenticity } \\
\text { (Existential Authenticity) }\end{array}$ & $\begin{array}{l}\text { EA1. To revere Korean culture. } \\
\text { EA2. To feel the meaning of Korean cultural heritage. } \\
\text { EA3. To feel the magical culture of Korea. } \\
\text { EA4. The scenery here is unique. } \\
\text { EA5. You can experience the life of other countries. }\end{array}$ \\
\hline Tourist Satisfaction & $\begin{array}{l}\text { TS1. The traditional culture in here is very charismatic. } \\
\text { TS2. The memories created by traveling here made me happy. } \\
\text { TS3. Traveling here is an advisable choice. } \\
\text { TS4. Traveling here is useful for me. } \\
\text { TS5. Traveling here is valuable. }\end{array}$ \\
\hline $\begin{array}{l}\text { Acculturation } \\
\text { (Integration) }\end{array}$ & $\begin{array}{l}\text { AI1. I feel more comfortable living in Korea. } \\
\text { AI2. I feel more comfortable speaking Korean. } \\
\text { AI3. I feel more comfortable being alone with Koreans. } \\
\text { AI4. I am more suitable for Korea society. } \\
\text { AI5. I prefer Korea culture. }\end{array}$ \\
\hline $\begin{array}{l}\text { Acculturation } \\
\text { (Assimilation) }\end{array}$ & $\begin{array}{l}\text { AA1. I feel comfortable living in Korea as well as in China. } \\
\text { AA2. I can speak Korean and Chinese. } \\
\text { AA3. I feel more comfortable being alone with Koreans and Chinese. } \\
\text { AA4. I am suitable for Korean society and China society. } \\
\text { AA5. I like Chinese culture as well as Korean culture. }\end{array}$ \\
\hline $\begin{array}{l}\text { Acculturation } \\
\text { (Separation) }\end{array}$ & $\begin{array}{l}\text { AS1. I feel more comfortable being alone with Chinese than Koreans. } \\
\text { AS2. Most of my friends are Chinese. } \\
\text { AS3. I go to Chinese get-togethers frequently. } \\
\text { AS4. I adapt to Chinese culture easier than Korean culture. } \\
\text { AS5. I am more comfortable and at ease when speaking Chinese. }\end{array}$ \\
\hline $\begin{array}{l}\text { Acculturation } \\
\text { (Marginalization) }\end{array}$ & $\begin{array}{l}\text { AM1. I feel that Chinese and Koreans dislike me. } \\
\text { AM2. I feel that it is difficult to make Chinese and Koreans understand me. } \\
\text { AM3. Sometimes I feel it is hard to make friends. } \\
\text { AM4. Sometimes I feel it is difficult to communicate with other people. } \\
\text { AM5. It is hard for others to accept me. }\end{array}$ \\
\hline
\end{tabular}

\section{(2). Tourist experience}

In order to have their own experience in a tourist attraction, modern tourists had prepared to interact with the experience that is provided by tourist destination [9]. Van Manen [10] described the experience as one of the special types of practice that people experience and perceive. Schmitt [11] defined the experience as all of the mental reactions of perceptual and rational aspects of human existence, including sensory experience by five senses, sensibility experience by heart, experience by thinking, and experience by the relationship with others. However, Shaw and Williams [12] suggested that tourist experience is composed of sensory experiences through the five senses and the rational experience of knowledge. In this study, we defined tourist experience as the comprehensive psychological responses of perceptual and rational experience in tourism. Thus, we use the survey on 
whether the tourism activities could bring a new experience and improve visitors' knowledge and cognition to represent tourist experience.

(3). Authenticity

The staged authenticity, first introduced by MacCannell [13], refers to the staging of local culture to create an impression of authenticity for a tourist audience. The key point here, is that the essence of the culture is the critical factor in determining the quality of the tourist experience. Thus, modern people want to experience the cultural authenticity of different historical periods, regions, and other people's lives [14]. Three different approaches (objectivism, constructivism, and postmodernism) are reviewed and analyzed by Wang [15]. As a result, three different types of authenticity (objective authenticity, constructed or symbolic authenticity, and existential authenticity) were clarified. Objective authenticity means the authenticity of the original or genuine authenticity of the tourist attractions. In this study, objective authenticity is measured by items, such as the authenticity of relics and the excellence of world cultural heritage. Constructed authenticity refers to the authenticity projected onto toured objects by tourists or tourism producers in terms of their imagery, expectations, preferences, beliefs, powers, etc. Constructed authenticity was measured by the cognition of traditional culture. Existential authenticity refers to a potential existential of human beings that are to be activated by tourist activities. In this study, existential authenticity is measured by whether the visitors feel the meaning, mystique, and uniqueness of Korean culture, regardless of whether the culture is real. In postmodern conditions, both objective and constructed authenticity, as object-related notions, can only explain a limited range of tourist experiences, whereas existential authenticity, as an activity-related situation, could explain a greater variety of tourist experiences.

(4). Tourist satisfaction

Tourist satisfaction is the ultimate goal of tourism. Satisfaction here refers to the psychological constitution in the subsequent stages of sightseeing [16]. Satisfaction related to tourism has been conceptualized and defined in various ways. Beard and Ragheb [17] have defined tourist satisfaction as the degree of affirmative emotion and awareness formed after an individual participates in selected leisure activities. Lounsbury and Polik [18] defined it as the tourist evaluation after the overall experience of tourism. Baker and Crompton [19] regarded tourist satisfaction as the emotional state after touring. Because our research object is Chinese people who have experienced world cultural heritage tourism in Korea, we defined tourist satisfaction as tourists' evaluation for world heritage tourism. Tourist satisfaction was measured by whether the visitors feel happy, valuable, and useful for the journey (Table 1).

\section{(5). Acculturation}

Acculturation is a concept that was introduced by the American Social Science Research Council in 1930s to analyze and record various social phenomena. Berry [20] suggested that the process of cultural adaptation consists of two dimensions (whether to maintain the cultural values and characteristics of one's country of origin, and whether to maintain relations with mainstream society) and four types (integration, assimilation, separation, and marginalization) on the levels of emotion, action, and cognitive field. Cultural integration requires maintaining both the cultural characteristics of the indigenous culture and the new culture. Assimilation is defined as the decision by individuals to forego maintaining their cultural identity and instead seek daily interaction with other cultures. In contrast, cultural separation occurs when individuals value retaining their original culture, while at the same time, wishing to avoid interactions with others in the new culture. When there is little possibility or interest in cultural maintenance (often for reasons of enforced cultural loss), and little interest in having relations with others in the new culture (often for reasons of exclusion or discrimination), the category marginalization is then applied. The items in the questionnaire for acculturation are designed according to the definitions of each concept. 


\subsection{Research Hypotheses}

(1). Cross-cultural awareness and authenticity

Authenticity plays a very important role in the whole process of tourism [1,21]. With higher cultural diversity awareness, the possibility of recognizing authenticity through tourism activities will be increased [22]. To study the relationship between cross-cultural awareness and authenticity, we propose the following hypotheses:

Hypotheses 1 (H1). Cross-cultural awareness of Chinese in Korea has a positive effect on authenticity.

Hypotheses 1a (H1a). Cross-cultural awareness of Chinese in Korea has a positive effect on objective authenticity. Hypotheses $\mathbf{1 b}$ (H1b). Cross-cultural awareness of Chinese in Korea has a positive effect on constructed authenticity. Hypotheses 1c (H1c). Cross-cultural awareness of Chinese in Korea has a positive effect on existential authenticity.

(2). Tourist experience and authenticity

Previous studies have suggested that there is a significant relationship between tourist experience and authenticity in World Cultural Heritage Sites of Korea [23-25]. Wang [15] has pointed out that existential authenticity can often have nothing to do with whether the objects toured are real. Pons [26] also supported this view. The current study sought to further investigate the relationship between tourist experience and authenticity by proposing the following hypotheses:

Hypotheses 2 (H2). Tourist experience has a positive effect on authenticity.

Hypotheses 2a (H2a). Tourist experience has a positive effect on objective authenticity.

Hypotheses $\mathbf{2 b} \mathbf{( H 2 b )}$. Tourist experience has a positive effect on constructed authenticity.

Hypotheses 2c (H2c). Tourist experience has a positive effect on existential authenticity.

(3). Authenticity and tourist satisfaction

Research regarding authenticity and tourist satisfaction is limited. Park [27] used visitors who participated in a celebration of cultural tourism and found that constructed and existential authenticity have positive effects on satisfaction. Cho [28] studied the motivation, authenticity, and the relations of satisfaction in the Nagan folk village of Korea and suggested that constructed authenticity and existential authenticity have positive effects on tourist satisfaction. Several studies have also shown that authenticity has positive effects on tourist satisfaction [29,30]. Based on these studies, the hypotheses about the relationship between authenticity and tourist satisfaction were established, as follows:

Hypotheses 3 (H3). Authenticity has a positive effect on tourist satisfaction.

Hypotheses 3a (H3a). Objective authenticity has a positive effect on tourist satisfaction.

Hypotheses $3 \mathbf{b} \mathbf{~ ( H 3 b ) . ~ C o n s t r u c t e d ~ a u t h e n t i c i t y ~ h a s ~ a ~ p o s i t i v e ~ e f f e c t ~ o n ~ t o u r i s t ~ s a t i s f a c t i o n . ~}$

Hypotheses 3c (H3c). Existential authenticity has a positive effect on tourist satisfaction.

(4). Tourist satisfaction and acculturation

The research on the direct and indirect relationship between tourist satisfaction and acculturation is very limited. Park [31] used immigrants who came from multicultural families to study the relationship between tourist satisfaction (emotional satisfaction, social environment satisfaction) and acculturation (integration, assimilation), and found that tourist satisfaction has a positive effect on acculturation. By studying the effects of tourist satisfaction and life satisfaction on cultural adaptation stress (perceived discrimination, homesickness, perceived hostility, cultural shock) of residents who escaped from North Korea, Song [32] found that tourist satisfaction has a negative 
effect on perceived discrimination and perceived hostility. Based on the previous studies above, we proposed the following hypotheses:

Hypotheses 4 (H4). Tourist satisfaction has a positive effect on acculturation.

Hypotheses 4a (H4a). Tourist satisfaction has a positive effect on integration.

Hypotheses $\mathbf{4 b} \mathbf{( H 4 b )}$. Tourist satisfaction has a positive effect on assimilation.

Hypotheses 4c (H4c). Tourist satisfaction has a positive effect on separation.

Hypotheses $4 \mathbf{d}(\mathbf{H} 4 \mathrm{~d})$. Tourist satisfaction has a positive effect on marginalization.

All the 4 hypotheses are shown in Figure 1.

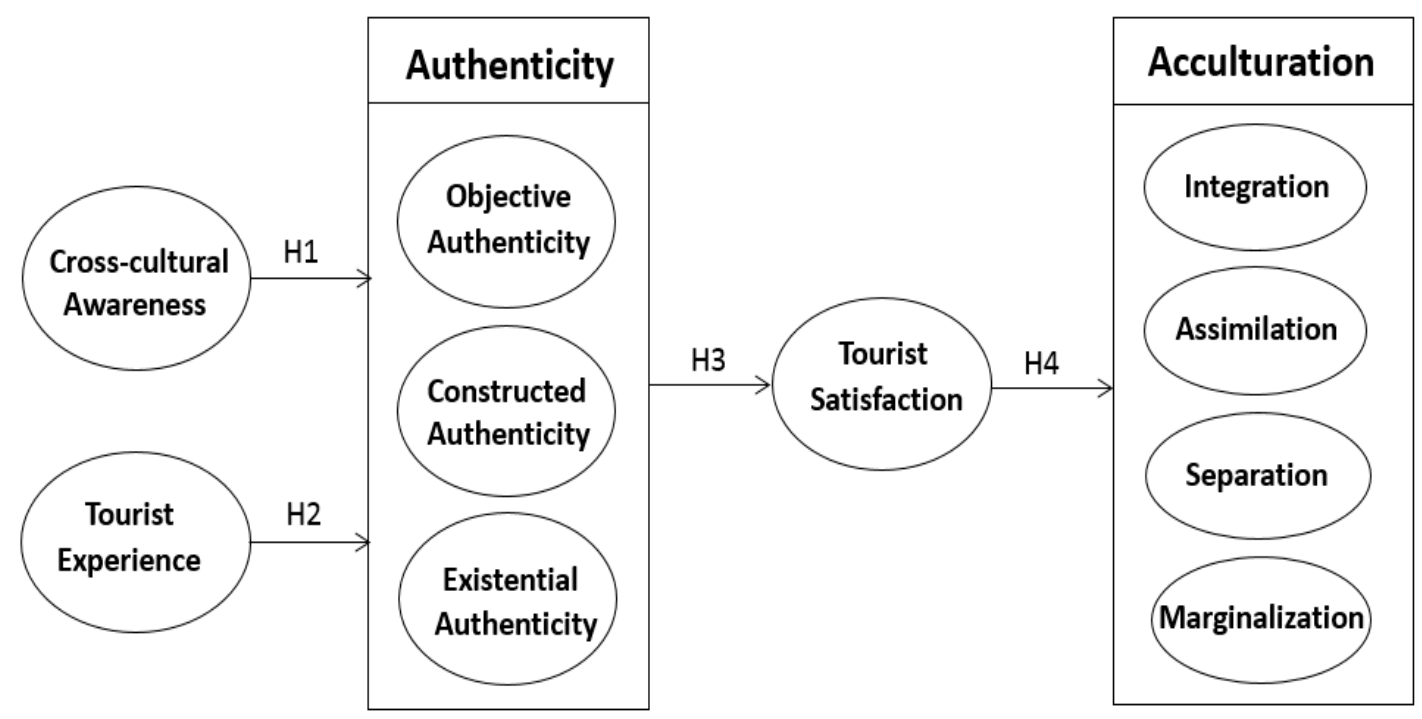

Figure 1. Proposed conceptual model regarding the influence of cross-cultural awareness and tourist experience on authenticity, tourist satisfaction, and acculturation.

\section{Methodology}

\subsection{Study Sites}

The sites that are investigated in this study are the Historic Villages of Korea: Hahoe and Yangdong, both of which are World Cultural Heritage Sites in Korea. Hahoe Village is one of the symbolic places where traditional Confucian culture is still maintained. Hahoe village has the following attractions: ran ritual program (traditional funeral rites demonstration and traditional wedding ceremony), folklore program (seasonal rituals and a master artisan, reenactment of traditional cultural life), educational program (special lecture of world cultural heritage, seowon stay, listening traditional lecture, tea culture, manners education, family motto writing experience, hwajeon game, visit and housekeeping education, traditional Korean house experience, traditional food, descendant puppet show). Yangdong Village, on the other hand, is one of the representative Banchon villages of Korea and has the largest scale and the longest history. It is the most valuable traditional village, preserving traditional culture, sightseeing, historical contents, etc. For more than 500 years, the Lee and Son families cooperated with each other in this village. In Yangdong village, the program includes a classroom on Confucian culture (household etiquette, wedding, festival), traditional experiences (tteok mallet pounding, honey cookie making, hanbok wearing, the teaching of traditional etiquette, orchid drawing, jegi kicking, calligraphy), and traditional Korean-style house experience. Therefore, these two places are suitable for studying visitors' experiences of Korean culture. 


\subsection{Data Collection}

We collected data by using convenience sampling and a self-administered questionnaire. We interviewed Chinese tourists (including immigrants, students, and workers) visiting the Historic Villages of Korea: Hahoe and Yangdong between 16 April 2016, and 8 May 2016, a period of 23 days. A total of 450 questionnaires were issued, and 430 were received for analysis.

In the questionnaire, we set up five items in order to determine cross-culture awareness, five items to determine tourist experience, 14 items to determine authenticity, five items to determine tourist satisfaction, and 20 items to determine acculturation (Table 1). Furthermore, we also set up six items to measure demographic characteristics: gender, age, marital status, education level, monthly income, and retention type. All of the variables using 5 -point Likert scale $(1=$ strongly disagree, $2=$ disagree, $3=$ neutral, $4=$ agree, $5=$ strongly agree), except for demographic characteristics.

\subsection{Statistical Analysis}

Frequency analysis was used to examine the demographic characteristics of samples. Confirmatory factor analysis (CFA) is used as a first step to assess the proposed measurement model in a structural equation model (SEM).

Subsequently, convergent and discriminant validity were used to assess the construct of this study. Convergent validity refers to the degree to which two measures of constructs are related. Convergent validity can be estimated using correlation coefficients. Discriminant validity tests whether concepts that are not supposed to be related are actually unrelated.

At last, SEM was used to examine the proposed theoretical model by using the index of the goodness-of-fit, such as $\chi^{2} / \mathrm{df}$, goodness of fit index (GFI), adjusted goodness of fit index (AGFI), normative fit index (NFI), comparative fit index (CFI), root mean square residual (RMR), root mean square error of approximation (RMSEA), and other fitting indices.

We used the SPSS 20.0 statistic program to perform frequency analysis, convergent validity, and discriminant validity. The CFA and SEM were carried out using AMOS 20.0.

\section{Results}

\subsection{Demographic Characteristics}

Demographic characteristics of the samples are shown in Table 2. There were 230 males (53.5\%) and 200 females (46.5\%). The most frequent age group sampled was people in their 20s, with 128 respondents $(29.8 \%)$. The majority of people, $277(64.4 \%)$, were unmarried. The most common retention type was service worker $(n=177 ; 41.1 \%)$, followed by foreign students and immigrants. Concerning educational attainment, people who were currently enrolled in a university or had graduated from university accounted for the highest percentage of respondents $(n=144 ; 33.5 \%)$, followed by those that are currently studying at or already graduated from college, postgraduates, graduates from senior high school, and others. Concerning monthly income, the most common response was a monthly income of 750 and below EUR $(n=66 ; 38.6 \%)$. The remaining responses, in descending order, were as follows: 750-1500 EUR, other, 1591-2250 EUR, 2251-3000 EUR, more than 3751 EUR, and 3001-3750 EUR. Finally, there were 177 foreign workers $(41.1 \%)$, which was the largest proportion, followed by foreign students and immigrants. 
Table 2. Characteristics of the respondents. $(n=430)$.

\begin{tabular}{|c|c|c|}
\hline \multicolumn{2}{|c|}{ Variables Data Category } & \multirow{3}{*}{$\begin{array}{c}\text { Number of Samples/Percentage (\%) } \\
230 /(53.5) \\
200 /(46.5)\end{array}$} \\
\hline & Male & \\
\hline Gender & Female & \\
\hline \multirow{6}{*}{ Age } & 18-19 years old & $12 /(2.8)$ \\
\hline & 20-29 years old & $128 /(29.8)$ \\
\hline & 30-39 years old & $60 /(14.0)$ \\
\hline & $40-49$ years old & $98 /(22.8)$ \\
\hline & 50-59 years old & $99 /(23.0)$ \\
\hline & 60 years old and above & $33 /(7.7)$ \\
\hline \multirow{3}{*}{ Marital status } & Married & $144 /(33.5)$ \\
\hline & Single & $277 /(64.4)$ \\
\hline & Other & $9 /(2.1)$ \\
\hline \multirow{3}{*}{ Retention type } & Immigrants & $104 /(24.2)$ \\
\hline & Worker & $177 /(41.1)$ \\
\hline & International student & $149 /(34.7)$ \\
\hline \multirow{5}{*}{ Education level } & Senior high school & $73 /(17.0)$ \\
\hline & College diploma & $84 /(19.5)$ \\
\hline & University diploma & $144 /(33.5)$ \\
\hline & Graduate school and above & $76 /(17.7)$ \\
\hline & Other & $53 /(12.3)$ \\
\hline \multirow{7}{*}{$\begin{array}{l}\text { Monthly income } \\
\text { (EUR) }\end{array}$} & 750 and below & $166 /(38.6)$ \\
\hline & 751-1500 & $82 /(19.1)$ \\
\hline & $1501-2250$ & $52 /(12.1)$ \\
\hline & $2251-3000$ & $25 /(5.8)$ \\
\hline & $3001-3750$ & $15 /(3.5)$ \\
\hline & More than 3751 & $17 /(4.0)$ \\
\hline & Other & $73 /(17.0)$ \\
\hline
\end{tabular}

\subsection{Confirmatory Factor Analysis}

The CFA results of the whole construct are presented in Table 3. All of the fit indices $\left(\chi^{2}=467.060\right.$, $\mathrm{df}=188, \mathrm{GFI}=0.905, \mathrm{AGFI}=0.887, \mathrm{NFI}=0.946, \mathrm{CFI}=0.967, \mathrm{RMR}=0.034$, and $\mathrm{RMSEA}=0.060$ ) showed satisfactory levels. The results indicate that the covariance matrix of the collected data was similar to the covariance matrix of the proposed model. All the Cronbach's $\alpha$ values are above 0.89 , exceeding the minimum standard for reliability of 0.7 recommended by [33].

Table 3. Results of the confirmatory factor analysis (CFA).

\begin{tabular}{|c|c|c|c|c|c|c|c|}
\hline \multicolumn{3}{|c|}{ Pathway } & \multicolumn{2}{|c|}{ Estimate } & \multirow{2}{*}{ S.E. } & \multirow{2}{*}{ C.R. } & \multirow{2}{*}{ Cronbach's $\alpha$} \\
\hline & & & Non-Standardized & Standardized & & & \\
\hline \multirow{5}{*}{$\begin{array}{l}\text { Cross-cultural } \\
\text { Awareness }\end{array}$} & \multirow{5}{*}{$\rightarrow$} & CC5 & 1.000 & 0.884 & & & \multirow{5}{*}{0.920} \\
\hline & & $\mathrm{CC} 4$ & 0.972 & 0.895 & 0.037 & $26.252^{* * *}$ & \\
\hline & & $\mathrm{CC} 3$ & 0.924 & 0.845 & 0.039 & $23.868^{* * *}$ & \\
\hline & & CC2 & 0.771 & 0.698 & 0.045 & $16.979 * * *$ & \\
\hline & & $\mathrm{CC} 1$ & 0.913 & 0.807 & 0.043 & $21.298^{* * *}$ & \\
\hline \multirow{5}{*}{$\begin{array}{l}\text { Tourist } \\
\text { Experience }\end{array}$} & \multirow{5}{*}{$\rightarrow$} & TX5 & 1.000 & 0.842 & & & \multirow{5}{*}{0.947} \\
\hline & & TX4 & 0.979 & 0.827 & 0.034 & $28.506^{* * *}$ & \\
\hline & & TX3 & 1.078 & 0.926 & 0.041 & $26.303^{* * *}$ & \\
\hline & & $\mathrm{TX} 2$ & 1.094 & 0.922 & 0.042 & $26.079 * * *$ & \\
\hline & & TX1 & 1.037 & 0.893 & 0.042 & $24.532 * * *$ & \\
\hline \multirow{3}{*}{ Authenticity } & \multirow{3}{*}{$\rightarrow$} & OA & 1.000 & 0.850 & & & \multirow{3}{*}{0.955} \\
\hline & & CA & 0.871 & 0.735 & 0.043 & $20.140^{* * *}$ & \\
\hline & & EA & 0.999 & 0.926 & 0.038 & $26.631 * * *$ & \\
\hline
\end{tabular}


Table 3. Cont.

\begin{tabular}{|c|c|c|c|c|c|c|c|}
\hline \multicolumn{3}{|c|}{ Pathway } & \multicolumn{2}{|c|}{ Estimate } & \multirow{2}{*}{ S.E. } & \multirow{2}{*}{ C.R. } & \multirow{2}{*}{ Cronbach's $\alpha$} \\
\hline & & & Non-Standardized & Standardized & & & \\
\hline \multirow{5}{*}{$\begin{array}{l}\text { Tourist } \\
\text { Satisfaction }\end{array}$} & \multirow{5}{*}{$\rightarrow$} & TS5 & 1.000 & 0.855 & & & \multirow{5}{*}{0.933} \\
\hline & & TS4 & 0.977 & 0.888 & 0.040 & $24.549 * * *$ & \\
\hline & & TS3 & 0.972 & 0.884 & 0.040 & $24.321^{* * *}$ & \\
\hline & & TS2 & 0.968 & 0.863 & 0.048 & $19.967^{* * *}$ & \\
\hline & & TS1 & 0.909 & 0.830 & 0.048 & $18.988^{* * *}$ & \\
\hline \multirow{4}{*}{ Acculturation } & \multirow{4}{*}{$\rightarrow$} & $\mathrm{AI}$ & 1.000 & 0.199 & & & \multirow{4}{*}{0.771} \\
\hline & & AA & 0.892 & 0.755 & 0.054 & $14.930^{* * *}$ & \\
\hline & & AS & 0.382 & 0.273 & 0.054 & $3.238^{* * *}$ & \\
\hline & & $\mathrm{AM}$ & 0.375 & 0.254 & 0.057 & $3.892^{* * *}$ & \\
\hline
\end{tabular}

Note: All the abbreviations of variables are shown in Table 1. All standardized factor loadings are significant at $p<0.01$.

\subsection{Convergent and Discriminant Validity}

Table 4 presents convergent and discriminant validity statistics. All of the average variance extracted (AVE) and composite reliability (C.R.) values for the multi-item scales were greater than the minimum levels of 0.5 and 0.7 , respectively [34], indicating a sufficient level of convergent validity for the measurement model. Concerning the discriminant validity of the constructs, the square root of AVE of each construct was greater than the correlation coefficients for the corresponding inter-constructs in most cases, which confirmed the discriminant validity of the constructs.

Table 4. Convergent and discriminant validity of the measurement model.

\begin{tabular}{|c|c|c|c|c|c|c|c|c|c|c|}
\hline & $\mathrm{CC}$ & TE & OA & CA & EA & TS & AI & AA & AS & AM \\
\hline $\mathrm{CC}$ & 1 & & & & & & & & & \\
\hline TE & $0.784^{* * *}$ & 1 & & & & & & & & \\
\hline OA & $0.745^{* * *}$ & $0.796^{* * *}$ & 1 & & & & & & & \\
\hline CA & $0.569^{* * *}$ & $0.657^{* * *}$ & $0.693^{* * *}$ & 1 & & & & & & \\
\hline EA & $0.679^{* * *}$ & $0.769^{* * *}$ & $0.780^{* * *}$ & $0.706^{* * *}$ & 1 & & & & & \\
\hline TS & $0.734^{* * *}$ & $0.806^{* * *}$ & $0.864^{* * *}$ & $0.650^{* * *}$ & $0.755^{* * *}$ & 1 & & & & \\
\hline AI & $0.145^{* * *}$ & $0.171^{* * *}$ & $0.152^{* * *}$ & $0.268^{* * *}$ & $0.191^{* * *}$ & $0.112^{* *}$ & 1 & & & \\
\hline AA & $0.578^{* * *}$ & $0.666^{* * *}$ & $0.667^{* * *}$ & $0.559^{* * *}$ & $0.691^{* * *}$ & $0.601^{* * *}$ & $0.172 * * *$ & 1 & & \\
\hline AS & -0.039 & 0.019 & -0.030 & -0.034 & -0.031 & -0.024 & -0.002 & 0.005 & 1 & \\
\hline AM & $-0.155^{* * *}$ & -0.095 & -0.095 & 0.008 & -0.089 & $-0.103^{* *}$ & -0.031 & -0.009 & 0.011 & 1 \\
\hline C.R. & 0.900 & 0.931 & 0.910 & 0.900 & 0.933 & 0.922 & 0.921 & 0.908 & 0.890 & 0.879 \\
\hline AVE & 0.645 & 0.729 & 0.672 & 0.692 & 0.737 & 0.704 & 0.701 & 0.665 & 0.622 & 0.599 \\
\hline$\sqrt{ }$ AVE & 0.803 & 0.854 & 0.820 & 0.832 & 0.858 & 0.839 & 0.837 & 0.815 & 0.787 & 0.774 \\
\hline
\end{tabular}

Note: C.R. = composite reliability, AVE = average variance extracted. The abbreviations are shown in Table 1. ${ }^{* *} p<0.05,{ }^{* * *} p<0.01$.

\subsection{Structural Equation Modeling}

Figure 2 summarizes the estimated results of the proposed research model. Results showed that $\chi^{2}=2235.568(p<0.01), \mathrm{df}=1046, \chi^{2} / \mathrm{df}=2.137, \mathrm{GFI}=0.811, \mathrm{AGFI}=0.788, \mathrm{NFI}=0.885, \mathrm{CFI}=0.935$, $\mathrm{RMR}=0.052$, and RMSEA $=0.052$. When compared with the general fitness index, the model satisfied the level of the benchmark in the study. Therefore, it is suitable for using this model. The results of SEM are shown in Figure 2 and Table 5. The square of coefficient of multiple correlations (SMC) could reflect an explanatory variance of each variable. Cross-cultural awareness and tourist experience could explain $78.2 \%, 48.4 \%$, and $64.9 \%$ of the variances in objective authenticity, constructed authenticity, and existential authenticity, respectively. Authenticity could account for $87.2 \%$ of the variance in tourist satisfaction. Tourist satisfaction accounts for $1.6 \%, 39.8 \%, 0.05 \%$, and $0.0 \%$ of the variance in integration, assimilation, separation, and marginalization, respectively. 


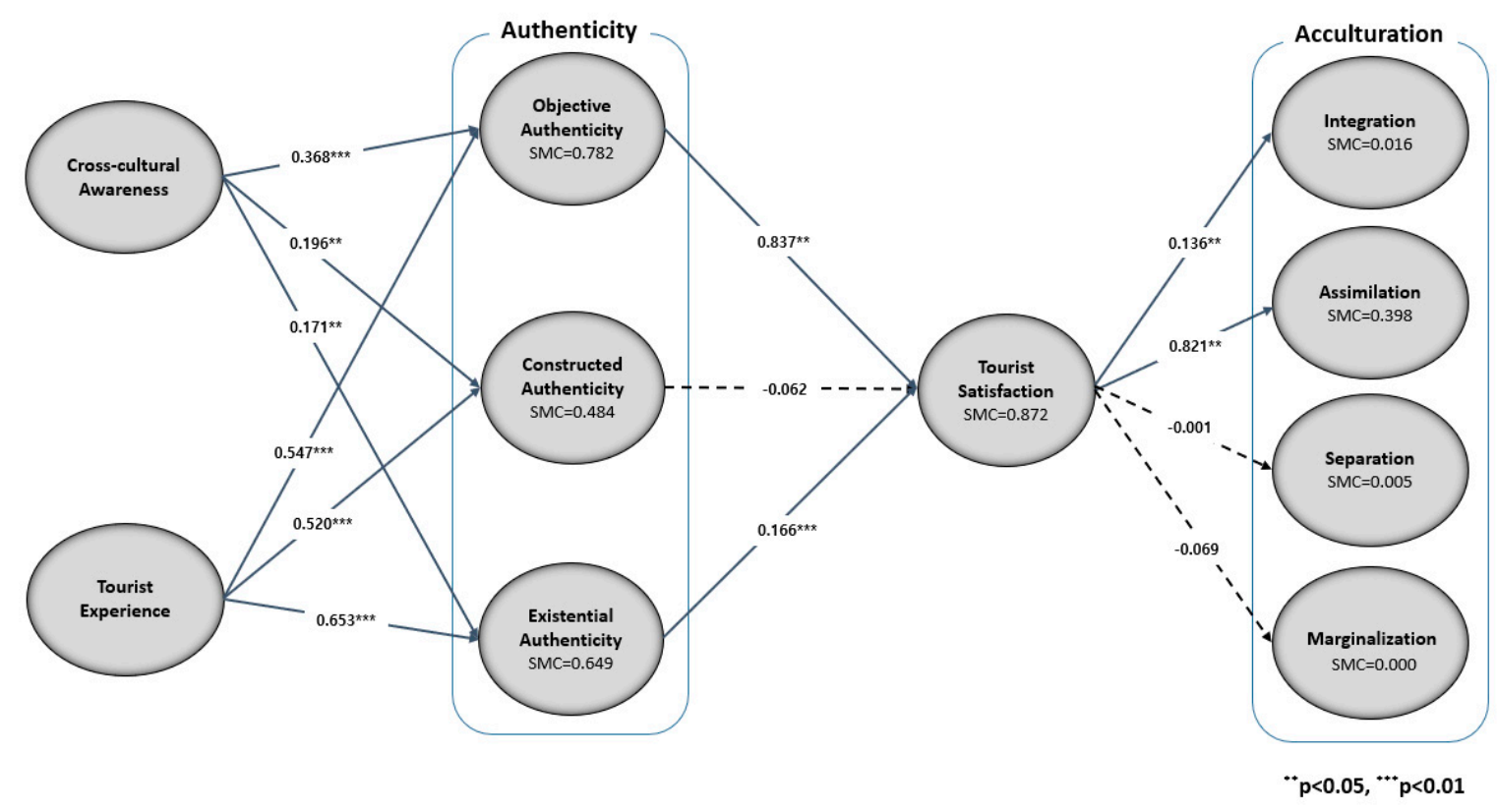

Figure 2. Results of Structural analysis. The standardized path coefficients and the square of coefficient of multiple correlations (SMC) are shown.

The following results could be summarized from the Table 5:

(1) Cross-Cultural awareness for Chinese in Korea is found to have a path coefficient value for the objective authenticity of 0.368 , and the $t$-value is $5.262(p<0.01)$. The value of the path coefficient for constructed authenticity is 0.196 , and the $t$-value is $2.118(p<0.01)$. The path coefficient value of the existential authenticity is 0.171 , and the $t$-value is $2.194(p<0.05)$. Therefore, cross-cultural awareness has a positive impact on authenticity, and thus Hypothesis 1 is supported.

(2) The path coefficient value of tourist experience for objective authenticity is 0.547 , and the $t$-value is 7.636. The value of the path coefficient for constructed authenticity is 0.520 , and the $t$-value is 5.578. The path coefficient value of existential authenticity is 0.171 , and the $t$-value is 8.097 . Therefore, tourist experience has a positive impact on authenticity, and thus Hypothesis 2 is supported.

(3) The path coefficient value of constructed authenticity for tourist satisfaction is 0.837 , and the $t$-value is $11.235(p<0.01)$. The path coefficient value for existential authenticity in tourist satisfaction is 0.166 , and the $t$-value is $3.144(p<0.01)$. However, the value of the path coefficient for constructed authenticity is -0.062 , and the $t$-value is $-1.458(p>0.05)$. Therefore, constructed and existential authenticity has a positive effect on tourist satisfaction. Hypothesis 3 is partially supported.

(4) The path coefficient value of tourist satisfaction for integration is 0.136 , and the $t$-value is $2.547(p<0.05)$. The path coefficient value in assimilation is 0.821 , and the $t$-value is 12.769 $(p<0.01)$. However, the value of the path coefficient in separation and marginalization is -0.001 and -0.069 , respectively, and the $t$-value is -0.013 and -1.308 , respectively. Therefore, Hypothesis 4 is partially supported. 
Table 5. Path coefficient of structural model testing.

\begin{tabular}{|c|c|c|c|c|c|c|}
\hline \multicolumn{3}{|c|}{ Pathway } & \multicolumn{2}{|c|}{ Estimate } & \multirow{2}{*}{ S.E. } & \multirow{2}{*}{$t$-Value } \\
\hline & & & Non-Standardized & Standardized & & \\
\hline \multirow[t]{3}{*}{ Cross-cultural awareness } & \multirow{3}{*}{$\rightarrow$} & Objective authenticity & 0.293 & 0.368 & 0.056 & $5.262 * * *$ \\
\hline & & Constructed authenticity & 0.191 & 0.196 & 0.090 & $2.118^{* *}$ \\
\hline & & Existential authenticity & 0.165 & 0.171 & 0.075 & $2.194^{* *}$ \\
\hline \multirow[t]{3}{*}{ Tourist experience } & \multirow{3}{*}{$\rightarrow$} & Objective authenticity & 0.401 & 0.547 & 0.052 & $7.636^{* * *}$ \\
\hline & & Constructed authenticity & 0.468 & 0.520 & 0.084 & $5.578^{* * *}$ \\
\hline & & Existential authenticity & 0.581 & 0.653 & 0.072 & $8.097^{* * *}$ \\
\hline \multirow{3}{*}{$\begin{array}{l}\text { Objective authenticity } \\
\text { Constructed authenticity } \\
\text { Existential authenticity }\end{array}$} & \multirow{3}{*}{$\rightarrow$} & \multirow{3}{*}{ Tourist satisfaction } & 0.984 & 0.837 & 0.088 & $11.235^{* * *}$ \\
\hline & & & -0.059 & -0.062 & 0.041 & -1.458 \\
\hline & & & 0.161 & 0.166 & 0.051 & $3.144^{* * *}$ \\
\hline \multirow[t]{4}{*}{ Tourist satisfaction } & \multirow{4}{*}{$\rightarrow$} & Integration & 0.096 & 0.136 & 0.038 & $2.547^{* *}$ \\
\hline & & Assimilation & 0.719 & 0.821 & 0.056 & $12.769^{* * *}$ \\
\hline & & Separation & -0.001 & -0.001 & 0.045 & -0.013 \\
\hline & & Marginalization & -0.049 & -0.069 & 0.038 & -1.308 \\
\hline
\end{tabular}

As mentioned above, we have summarized the tests of all the hypotheses in Table 6 . All of the hypotheses in Hypothesis 1 and Hypothesis 2 are supported. Cross-cultural awareness and tourist experience of Chinese in Korea have a positive effect on authenticity. In Hypotheses 3 and 4, part of the subordinate hypotheses is rejected. Objective authenticity and existential authenticity has a positive effect on tourist satisfaction, and tourist satisfaction has a positive effect on integration and assimilation.

Table 6. Verification result of all hypotheses proposed in this study.

\begin{tabular}{lll}
\hline Hypothesis & & Support/Not \\
\hline H1 & Cross-cultural awareness of Chinese in Korea has a positive effect on authenticity. & Supported \\
H1a & Cross-cultural awareness of Chinese in Korea has a positive effect on objective authenticity. & Supported \\
H1b & Cross-cultural awareness of Chinese in Korea has a positive effect on constructed authenticity. & Supported \\
H1c & Cross-cultural awareness of Chinese in Korea has a positive effect on existential authenticity. & Supported \\
\hline H2 & Tourist experience has a positive effect on authenticity. & Supported \\
H2a & Tourist experience has a positive effect on objective authenticity. & Supported \\
H2b & Tourist experience has a positive effect on constructed authenticity. & Supported \\
H2c & Tourist experience has a positive effect on existential authenticity. & Supported \\
\hline H3 & Authenticity has a positive effect on tourist satisfaction. & Partly supported \\
H3a & Objective authenticity has a positive effect on tourist satisfaction. & Supported \\
H3b & Constructed authenticity has a positive effect on tourist satisfaction. & Not Supported \\
H3c & Existential authenticity has a positive effect on tourist satisfaction. & Supported \\
\hline H4 & Tourist satisfaction has a positive effect on acculturation. & Partly supported \\
H4a & Tourist satisfaction has a positive effect on integration. & Supported \\
H4b & Tourist satisfaction has a positive effect on assimilation. & Supported \\
H4c & Tourist satisfaction has a positive effect on separation. & Not Supported \\
H4d & Tourist satisfaction has a positive effect on marginalization. & Not Supported \\
\hline
\end{tabular}

\section{Conclusions}

\subsection{Contribution}

Aiming to assess the influence of cross-cultural awareness and tourist experience on authenticity, tourist satisfaction, and acculturation in World Cultural Heritage Sites of Korea, this study used 430 questionnaires from Chinese in Korea who visited the World Cultural Heritage Sites for analysis. The confirmatory factor analysis and structural equation model were used to verify the proposed hypotheses. The conclusions are as follows.

(1) The perception of Chinese culture and other different cultures by the Chinese people in Korea shows a positive effect on objective authenticity, constructed authenticity, and existential authenticity, which supported the conclusion of previous studies [35,36]. Chinese in Korea with higher cultural awareness had more interest in the historical and cultural heritage of the World Cultural Heritage Sites. 
(2) Tourism experience has a positive effect on objective authenticity, constructed authenticity, and existential authenticity. This result supports the findings of several previous studies [23-25]. Our research also shows that tourists can understand the tradition, history, architecture, and lifestyle of the historical villages of Korea through the tourism experience.

(3) The objective authenticity and existential authenticity have a positive effect on tourist satisfaction, which was in accordance with the previous studies [27-30]. Especially in the World Cultural Heritage Sites, there is more demand from Chinese in Korea for tourist attractions, historic buildings, as well as the overall composition, environment, and physical handicrafts when compared to the pursuit of fun and pleasure.

(4) Tourist satisfaction has a positive effect on cultural integration and assimilation. This result reaffirms that there is a significant relationship between tourist satisfaction and acculturation, as suggested by Zhang and Cho [4], Park [31], and Song [32].

(5) Tourist satisfaction has a negative influence on separation and marginalization. Increasing tourist satisfaction can prevent cultural separation and marginalization.

Overall, the model that is presented in this study systemically revealed the relationship between cross-cultural awareness, tourism experience, authenticity, tourist satisfaction, and cultural adaptation. The methods and conclusions in this study provide a reference for studying the role of tourism on cultural acculturation. Also, we concluded that objective authenticity influences cultural acculturation through tourist satisfaction. Therefore, this study highlights the importance of the effective management, protection, and sustainable development of World Cultural Heritage Sites.

\subsection{Managerial Implications}

The Korea government is always developing and preserving authentic Korean culture through developing and preserving the World Cultural Heritage Sites. If such efforts are continued, the recognition of cross-cultural awareness is heightened, and then the interest in the authenticity of the World Cultural Heritage Sites will increase. This will help the sustainable development of tourism industry.

In addition, it is necessary to develop programs to experience authenticity and the value of traditional culture, such as programs in which people can experience and touch the true nature and value of traditional culture. In particular, in the process of modernization, objective authenticity is weakening gradually. We should try to recognize and enhance existential authenticity. For example, virtual reality, augmented reality and intelligent machines could be used to introduce more programs so that visitors would have more varied experiences.

Since tourist satisfaction has a positive effect on cultural integration and assimilation, management personnel in the tourism industry should make various efforts to improve tourist satisfaction, for example, by developing and introducing diverse projects, by persistently maintaining the quality of service and by providing more help to people so that they will accept and adapt to the new culture. Also, the world culture sites could make use of the digital traces left behind by the tourists from online interaction, networks, sensors, etc., which can enhance the tourist experience through co-creation [37]. To solve difficulties due to cultural differences, foreigners, such as immigrants, international students, and workers, who were the focus of this study, should be actively encouraged to engage in tourism activities and be provided with opportunities to enhance adaptation to Korean society and culture. In addition, for Chinese in Korea, if acculturation can be done quickly, social problems that are caused by intercultural conflicts can be prevented.

\subsection{Limitations and Future Research Directions}

There are still several limitations in this study. We only investigated Chinese people (immigrants, foreign students, workers) in Korea. However, it is necessary to study visitors from other countries for a more generalized conclusion. Furthermore, the prior experience on the tourism destinations through 
media and social network affects tourist experience and re-visit intention [38]. Therefore, in the future, we should consider the impact of the prior experience.

In addition, Chinese people with a different length of time staying in Korea may experience different levels of prejudice and discrimination, which may cause a difference in acculturation. Also, to establish causation between variables, other types of design are required in future. For instance, to show that the experience of authenticity while visiting villages affects tourism satisfaction, it would also be necessary to collect data from equivalent samples of tourists who did not visit villages.

Acknowledgments: This research was supported by the project of Chinese Academy of Sciences (No.: KGFZD-135-17-009-1).

Author Contributions: Hao Zhang and Taeyoung Cho conceived and designed the research; Taeyoung Cho contributed analysis tools; Hao Zhang collected the data, performed the statistical analysis and wrote the paper. Huanjiong Wang and Quansheng Ge supervised the overall research project and significantly contributed to the editing of the manuscript.

Conflicts of Interest: The authors declare no conflict of interest.

\section{References}

1. Richards, G.; Wilson, J. Conclusions: Widening perspectives in backpacker research. In The Global Nomad: Backpacker Travel in Theory and Practice; Research, G., Wilson, J., Eds.; Channel View Publications: Bristol, UK, 2007; Volume 14, pp. 253-297.

2. South Korea's Ministry of Culture. Sports and Tourism; MCST: Sejong City, Korea, 2017.

3. Cho, T. The Effect of Cultural Tour Experience on Authenticity, Tourism Satisfaction, and Quality of Life. Ph.D. Thesis, Graduate School of Dongguk University, Gyeongju-si, Korea, 2008.

4. Zhang, H.; Cho, T. The relationship among Authenticity of World cultural Heritage tourist attraction tourist satisfaction and culture adaptation: Based on Chinese tourist in Korea. J. Hosp. Tour. Stud. 2016, 18, 1-22.

5. Irimiás, A. Traveling patterns of Chinese immigrants living. J. China Tour. Res. 2013, 9, 180-190. [CrossRef]

6. Dodd, C. Dynamics of Intercultural Communication, 5th ed.; McGraw-Hill Publishing: New York, NY, USA, 1998.

7. Dodd, C. Intercultural readiness assessment for pre-departure candidates. J. Intercult. Commun. Stud. 2007, $16,1-17$.

8. Hall, C. Response to Yeoman et al.: The fakery of the authentic tourist. Tour. Manag. 2007, 28, 1139-1140. [CrossRef]

9. Buonincontri, P.; Micera, R. The experience co-creation in smart tourism destinations: A multiple case analysis of European destinations. Inf. Technol. Tour. 2016, 16, 285-315. [CrossRef]

10. Van Manen, M. Researching Lived Experience: Human Science for an Action Sensitive Pedagogy; State University of New York Press: New York, NY, USA, 1990.

11. Schmitt, B.H. Experiential Marketing; Free Press: New York, NY, USA, 1999.

12. Shaw, G.; Williams, A. Critical Issues in Tourism: A Geographical Perspective, 2nd ed.; Malden, M.A., Ed.; Blawell Publishers Inc.: Hovoken, NJ, USA, 2002.

13. MacCannell, D. Staged authenticity: Arrangements of social space in tourist settings. Am. J. Sociol. 1973, 79, 589-603. [CrossRef]

14. MacCannell, D. The Tourist; Schocken Books: New York, NY, USA, 1976.

15. Wang, N. Rethinking authenticity in tourism experience. Ann. Tour. Res. 1999, 26, 349-370. [CrossRef]

16. Ko, D. A Critical review of tourism behavioral literature: With an emphasis on articles appeared in ATR. J. Tour. Sci. 1998, 22, 207-229.

17. Beard, J.; Ragheb, M. Measuring leisure satisfaction. J. Leis. Res. 1980, 12, 20-33. [CrossRef]

18. Lounsbury, J.; Polik, J. Leisure needs and vacation satisfaction. Leis. Sci. 1992, 14, 105-119. [CrossRef]

19. Baker, A.; Crompton, L. Quality, Satisfaction and behavioral intentions. Ann. Tour. Res. 2000, 27, 785-804. [CrossRef]

20. Berry, J. Immigration acculturation and adaptation Applied Psychology. Appl. Psychol. 1997, 46, 5-34.

21. Huxley, L. Western backpackers and the global experience: An exploration of young people's interactions with local cultures. Tour. Cult. Commun. 2004, 5, 37-44. [CrossRef] 
22. Fontaine, G. Motivational factors of international travelers. Psychol. Rep. 1993, 72, 1106. [CrossRef]

23. Cohen, E. Authenticity and commoditization in tourism. Ann. Tour. Res. 1993, 15, 371-386. [CrossRef]

24. Asplet, M.; Cooper, M. Cultural designs in New Zealand souvenir clothing: The question of authenticity. Tour. Manag. 2000, 21, 307-312. [CrossRef]

25. Steiner, C.; Reisinger, Y. Understanding existential authenticity. Ann. Tour. Res. 2006, 33, 299-328. [CrossRef]

26. Pons, P. Being-on-holiday. Tourist dwelling, bodies and place. Tour. Stud. 2003, 3, 47-66. [CrossRef]

27. Park, J. Relationship between Participants' Perception of Authenticity and Values of Participation: Focusing on Millennial Anniversary of the Tripitaka Koreana. Master's Thesis, Graduate School, Kyung Hee University, Seoul, Korea, 2012.

28. Cho, M. A study of authenticity in traditional Korean folk villages. Int. J. Hosp. Tour. Adm. 2012, 13, $145-171$. [CrossRef]

29. Moscardo, G.; Pearce, P. Historic Theme Parks. An Australian experience in authenticity. Ann. Tour. Res. 1986, 13, 467-479. [CrossRef]

30. Chhabra, D.; Healy, R.; Sills, E. Staged authenticity and heritage tourism. Ann. Tour. Res. 2003, 30, 702-719. [CrossRef]

31. Park, S. Effect of Multi-Cultural Family' Social Adjustment Ability on Satisfaction through Cultural Tourism: Focusing on Moderating Variable of Cultural Adjustment and Psychological Well-Being. Ph.D. Thesis, Graduate School, Tong Myong University, Busan, Korea, 2011.

32. Song, J. The Effect of the Tourism Satisfaction and the Satisfaction with Life on the Acculturative Stress of North Korean Defectors. J. Tour. Leis. Res. 2006, 18, 251-271.

33. Nunnally, J.; Bernstein, I. Psychometric Theory, 3rd ed.; McGraw-Hill: New York, NY, USA, 1994.

34. Hair, J.F., Jr.; Black, W.C.; Babin, B.J.; Anderson, R.E.; Tatham, R.L. Multivariate Data Analysis; Pearson: London, UK, 2006.

35. Zhang, H.; Se, T. A research on structural relationships between Cross-Cultural Awareness, Authenticity and Tourist experience of Chinese tourists: Centered on Korean World Cultural Heritage Travel Destination. Korean J. Tour. Res. 2014, 29, 201-223.

36. Zhang, H.; Cho, T. The impact of cross-cultural and tourist experience on the authenticity and tourist satisfaction: Focus on Chinese tourists in the world cultural heritage of Korea tour destinations. J. Tour. Manag. Res. 2016, 20, 199-222.

37. Buonincontri, P.; Morvillo, A.; Okumus, F.; Niekerk, M. Managing the experience co-creation process in tourism destinations: Empirical findings from Naples. Tour. Manag. 2017, 62, 264-277. [CrossRef]

38. Dedeoglu, B.; Bilgihan, A.; Ye, B.H.; Buonincontri, P.; Okumus, F. The impact of servicescape on hedonic value and behavioral intentions: The importance of previous experience. Int. J. Hosp. Manag. 2018, 72, 10-20. [CrossRef]

(C) 2018 by the authors. Licensee MDPI, Basel, Switzerland. This article is an open access article distributed under the terms and conditions of the Creative Commons Attribution (CC BY) license (http:// creativecommons.org/licenses/by/4.0/). 